Tarbawy : Jurnal Pendidikan Islam

ISSN : 2407-4462 (Cetak), 2614-5812 (Elektronik)

Vol. 8, No. 2, 2021, Hal. 67-77

DOI: https://doi.org/10.32923/tarbawy.v8i2.1925

\title{
Hibridisasi Pendidikan Islam Dan Neurosains: Implementasi Paradigma Integrasi Keilmuan Dalam Pendidikan Islam
}

\author{
Listiana Ayu Indarwati ${ }^{1}$, Iffatur Rohmah ${ }^{2}$, Dahlia Fitri Ichsanti ${ }^{3}$, Ridho Safrial $^{4}$, Rahma Sari ${ }^{5}$
}

${ }^{1}$ Universitas Ahmad Dahlan

${ }^{2}$ Universitas Ahmad Dahlan

${ }^{3}$ Universitas Ahmad Dahlan

${ }^{4}$ Universitas Ahmad Dahlan

${ }^{5}$ Universitas Ahmad Dahlan

\section{Info Artikel : \\ Diterima 8 Agustus 2021 \\ Direvisi 25 september, 2021 \\ Dipublikasikan 21 oktober 2021}

\section{Kata Kunci:}

hibridisasi,

kebijakan pendidikan,

lembaga pendidikan tinggi.

\section{Keywords:}

hybridization,

education policy,

higher education institutions.

\begin{abstract}
ABSTRAK
Tulisan ini hendak mempersoalkan sekaligus memberi solusi terhadap permasalahan dualisme kebijakan lembaga pendidikan tinggi Islam. Upaya memadukan pendidikan agama dan pendidikan umum belum sampai pada kata memuaskan. Beberapa konsep sudah ditawarkan namun masih menyisakan persoalan berupa dualisme kebijakan lembaga pendidikan tinggi Islam. Oleh karena itu, kami menawarkan konsep tentang hibridisasi lembaga pendidikan tinggi. Usaha ini sangat mendesak untuk dilakukan karena ada kecenderungan lembaga pendidikan tinggi Islam dan lembaga pendidikan tinggi umum justru semakin berjalan sendiri-sendiri, sekalipun sudah ada tawaran konsep tentang Islamisasi ilmu, Islam sebagai ilmu, ataupun integrasi dan interkoneksi keilmuan.
\end{abstract}

\begin{abstract}
This paper wants to question as well as provide solutions to the problem of dualism in Islamic higher education institutions' policies. Efforts to combine religious education and general education have not reached a satisfactory level. Several concepts have been offered but there are still problems in the form of dualism in the policies of Islamic higher education institutions. Therefore, we offer the concept of hybridization of higher education institutions. This effort is very urgent to do because there is a tendency for Islamic higher education institutions and general higher education institutions to run independently, even though there have been offers of concepts about the Islamization of science, Islam as a science, or the integration and interconnection of science.
\end{abstract} original work is properly cited. $\mathbb{C} 2019$ by author.

\section{Koresponden:}

listiana

listiana2000031133@webmail.uad.ac.id

\section{Pendahuluan}

Islam mengalami keterpurukan yang panjang dalam bidang ilmu pengetahuan. Masa kejayaan Islam terhenti pada dinasti Abbasiyah pada abad pertengahan. Sampai saat ini, dalam bidang ilmu pengetahuan, para ilmuan dan umat Islam secara umum masih selalu mengekor kepada Barat. Hampir seluruhnya penemuan baru dan teori ilmu modren selalu dilahirkan dari rahim Barat. Memang dari ilmuilmu baru yang dilahirkan tersebut ada yang memberikan sumbangsih positif terhadap kemajuan zaman. Namun demikian, ada sebagian ilmu yang lahir justru menimbulkan kerusakan pada alam dan logika untuk saling menghancurkan antar sesama manusia. Hal ini terjadi karena ilmu yang lahir adalah ilmu sekuler murni yang tidak dilandasi dengan etika dan moral yang kental. Untuk itu sudah saatnya Islam mengambil alih kendali keilmuan agar tugas masnusia khalifah benar-benar dapat diemban dengan kaffah. 
Ilmu pengetahuan dapat mengandung nilai yang membawa kebaikan untuk alam semesta dan orang yang akan menggunakan ilmu itu akan dilandasi dengan nilai-nilai Islam universal untuk menghasilkan kemanfaatan bagi seluruh makhluk didunia ini.

Sudah ada upaya yang dilakukan umat Islam untuk bangkit dari keterpurukan dan mengambil alih ilmu pengetahuan. Salah satu upaya yang ditempuh adalah mendirikan dan mengembangkan lembaga pendidikan Islam mulai dari madrasah sampai perguruan tinggi. Namun demikian, ada ancaman serius yang dihadapi lembaga pendidikan Islam khususnya lembaga pendidikan tinggi agama Islam. Ancaman tersebut berupa kurang diminatinya fakultas-fakultas dan jurusan yang dibuka oleh lembaga pendidikan tinggi Islam berupa fakultas yang mengkaji tentang Islam normatif. Hal ini dikarenakan Islam normatif dianggap tidak dapat menyelesaikan problem dan tantangan modernisasi. Nasib yang lebih baik dialami oleh lembaga pendidikan Islam pada level pendidikan dasar, menengah, dan atas. Banyak contoh madrasah atau sekolah umum yang berlabelkan Islam sangat diminati oleh masyarakat. Bahkan pesantren yang dulunya identik sebagai tempat belajar bagi masyarakat ekonomi menengah kebawah, kini bertransformasi menjadi pesantren modern dan menjadi tujuan utama orang tua dari kalangan menengah keatas untuk mempercayakan pendidikan anak-anaknya.

Hal ini terjadi karena banyak madrasah, sekolah, dan pesantren yang menawarkan menu baru dalam "menjual" materi dan konsep pembelajaran mereka. Misalnya madrasah atau pesantren yang menawarkan penguasaan ilmu alat (bahasa Inggris-Arab). Menu ini dimanfaatkan oleh para orang tua sebagai bekal anaknya untuk melajutkan ke pendidikan tinggi di luar negeri. Sekali lagi sebagian besar masyarakat hanya berminat kepada pendidikan dasar sampai menengah Islam untuk mempersiapkan anaknya melanjutkan ke pendidikan tinggi umum atau bahkan sebagai batu loncatan belajar di luar negeri.

Menghadapi tantangan zaman yang semakin kompleks lembaga pendidikan Islam dituntun untuk mampu beradaptasi dengan wacana keilmuan modern danpara alumni dituntut mampu mengamalkan ilmu pengatahuannya dilandasi dengan etika dan moral yang dapat menghasilkan manfaat yang lebih luas dan bijak. Jika tantangan tersebut tidak mampu dijawab maka berakhirlah sudah kejayaan lembaga pendidikan Islam yang digadang-gadang sebagai produk unggulan umat Islam. Memang benar, dalam dasa warsa terakhir dikalangan dunia Islam muncul dan berkembang kesadaran urgensi dan rekontruksi peradaban Islam melalui penguasaan sains dan teknologi. Tetapi, tantangan-tantangan yang dihadapi luarbiasa kompleks baik secara internal maupun eksternal. ${ }^{1}$ Oleh karena itu, diperlukan pemikiran jernih dan luas serta perlu unsur kehati-hatian dalam menentukan dan memutuskan kebijakan tentang bagaimana nasib lembaga pendidikan Islam di masa yang akan datang.

Saat ini sudah ada banyak usaha yang dilakukan dalam rangka membenahi lembaga pendidikan tinggi Islam agar mampu eksis dan survive di tengah tantangan zaman. Salah satu usaha yang dimaksud adalah adanya tren trasnformasi lembaga pendidikan tinggi Islam dalam hal ini STAIN dan IAIN menjadi Universitas Islam Negeri atau UIN. Dengan demikian, lembaga pendidikan Islam yang mulanya hanya dapat membuka fakultas agama,maka setelah menjadi UIN lembaga tersebut dapat membukan fakultas umum. Dengan demikian, akhirnya minat masyarakat akan kembali tinggi apalagi tarif biaya di UIN jauh lebih rendah dibandingkan dilembaga pendidikan umum.

Namun demikian, kebijakan transformasi atau konversi IAIN menjadi UIN nampaknya menyisakan dampak negatif yang ditinggalkan. Jika pada awalnya IAIN memiliki fakultas agama (Tarbiyah, Syariah, Dakwah, Adab, dan Ushuludin), maka konsekuensi logis yang ditimbulkan dari konversi tersebut adalah UIN harus membuka fakultas-fakultas umum. Akibat dari transformasi ini, akan muncul dua kebijakan yang akan mengatur satu tubuh UIN. Singkatnya dalam satu tubuh UIN akan berada dalam dua kendali kebijakan yaitu fakultas agama berada di bawah Kementerian agama dan fakultas umum berada dibawah Kementerian pendidikan dan kebudayaan. Sekilas permasalahan ini tidak 
akan menimbulkan dampak besar, namun adanya tumpang tindih kebijakan dan adanya kemungkinan kebijakan yang tidak selaras dapat menjadikan tubuh UIN menjadi "sakit" karena tak tentu arah dan memikul beban yang berat.

Selain permasalahan tersebut, masih ada hal urgen dalam tubuh pendidikan Islam yang terkadang dikesampingkan. Selama ini, materi-materi agama Islam yang diajarkan adalah materi yang berasal dari buku paket yang diberikan oleh Kementerian agama. Kita kadang lupa bahwa pada realitasnya dalam tubuh umat Islam di Indonesia, banyak perbedaan-perbedaan pemahaman yang terjadi misalnya urusan ibadah, muamalah dan permasalahan khilafiyah. Perbedaan pemahaman tersebut seolah tidak dihirauhakan, salah satu contohnya adalah pada buku materi pelajaran fiqih di sekolah, madasarah bahkan sampai ke perguruan tinggi. Bacaan-bacaan doa shalathanya dimuat bacaan dari salah satu sumber saja, padahal bacaan tersebut yang sama-sama shahih ada banyak macam.

Pada lingkaran akademis fenomena tersebut saya sebut sebagai dualisme kebijakan dalam pendidikan Islam. Selain permasalahan dualisme, tubuh pendidikan Islam juga terjangkit penyakit saling memusuhi dan merasa paling benar atas keyakinan agamanya yang ditimbulkan dari materi pelajaran agama yang terkesan "memaksa" kepada peserta didik dan menafikan keberagaman pemahaman yang tumbuh. Untuk itu tulisan ini hendak merespon permasalahan tersebut dengan menggagas format pendidikan Islam baru baik dalam hal kelembagaan maupun dalam hal materi pembelajaran. Dengan demikian, besar harapan saya bahwa masa depan pendidikan Islam akan lebih cerah dan nilai-nilai Islam yang universal akan mampu membawa seluruh komponen pendidikan menuju siratal-mustaqim mewujudkan ulama intelek dan intelek ulama.

\section{Akar Dikotomi dan Dualisme Pendidikan Tinggi Islam}

Sebelum jauh melangkah kebelakang menelusuri akar dikotomi dan dualisme kebijakan lembaga pendidikan Islam, ada baiknya perlu adanya persamaan persepsi awal tantang makna dikotomi dan dualisme itu sendiri. Hal ini dimaksudkan agar kita mendapatkan titik awal untuk melangkah menelusuri jalan panjang menuju akar dikotomi dan dualisme kebijakan lembaga pendidikan tinggi Islam.

Dalam konteks pendidikan, Marwan Sarijo ${ }^{2}$ menyatakan bahwa istilah dualisme dan dikotomi memiliki makna yang sama yaitu pemisahanan tara pendidikan umum dari pendidikan agama. Berangkat dari pemaknaan singkat tersebut maka dualism dan dikotomi pendidikan adalah pemisahan system pendidikan antara pendidikan Islam dan pendidikan umum yang memisahkan kesadaran keagamaan dan ilmu pengetahuan atau ilmu umum.Maka yang dimaksud pendidikan agama adalah materi-materi yang membahas permasalahan agama dalam bingkai agama normatif dan yang dimaksud ilmu umum adalah ilmu yang berisi materinon-agama berupa ilmu dalam bingkai historis. Dualisme dan dikotomi ini, bukan hanya pada tataran pemilahan tetapi masuk pada wilayah pemisahan. Dalam operasionalnya, pada madrasah dan sekolah terjadi pemisahan antara mata pelajaran umum dengan mata pelajaran agama. Dalam pendidikan tinggi Islam pemisahan terjadi pemisahan kebijakan fakultas agama dan fakultas umum.

Fenomena dikotomi ini, memicu anggapan adanya kemunduran keilmuan dalam dunia Islam. Kemunduran penguasaan ilmu pengetahuan dalam dunia Islam menurut Fazlurrahman diakibatkan adanya dikotomi ilmu, yaitu ilmu tradisional (agama) dan ilmu sekuler-modern(umum). ${ }^{3}$ Namun demikian, jika kemunduran umat Islam hanya di akibatkan karena dikotomi ilmu yang hanya sekedar membedakan atau mengklasifikasi ilmu menjadi "ilmu agama" dan "ilmu sekuler", maka sebanarnya tidak akan menjadi masalah yang besar jika tidak berlebihan. Dalam dunia Islam probelmatika dikotomi sebenarnya bukan hal yang baru. Tetapi pada mulanya permasalahan dikotomi tersebut tidak menimbulkan banyak problem dalam sistem pendidikan islam, hingga sistem pendidikan sekuler Barat diperkenalkan ke dunia Islam melalui imperialisme. ${ }^{4}$ 
Dari sudut pandang sejarah, dikotomi ilmu telah dimulai sejak zaman pertengahan meski pada mulanya, ilmu pengetahuan dan teknologi sudah sangat berkembang dikalangan umat Islam. Zaman pertengahan tersebut adalah ketika dinasti ummayah berkuasa. Dinasti umayah merupakan masa tunas perkembangan intelektual Islam. ${ }^{5}$ Namun demikian, tradisi keilmuan mengalami kemajuan sangat pesat pada masa Abbasiyah, penerjemahan naskah-naskah kuno,penemuan ilmu-ilmu hitung dan fisika hingga pendirian Baitul hikmah yang menjadi tanda mercusuar dari peradaban Islam. Masa Abbasiyah ini dikenal sebagai masa puncak kejayaan Islam.

Akan tetapi seperti yang kita ketahui bersama bahwa pada peradaban selanjutnya panggung kejayaan ilmu pengetahuan dalam dunia Islam hamper sepenuhnya runtuh. Umat Islam bahkan secara sadar memperlakukan diskrimininasi terhadap "ilmu-ilmu umum" yang dinilai hanya mempelajari ilmu sekuler yang sama sekali tidak bersentuhan dengan Islam. Sedangkan "ilmu agama" yang mempelajari wilayah agama dalam bingkai normatif dipandang sebagai sebuah kajian keilmuan yang paling utama dipelajari. Dengan demikian, ilmu umum dianggap sekuler atau bahkan dianggap ilmu kafir yang haram dipelajari karena tidak akan mendekatkan Pada Tuhan, sebaliknya ilmu tersebut dianggap akan jauh memisahkan manusia dari Tuhannya.

Dari pemahaman dikotomik tersebut, berkembanglah pemahaman bahwa ilmu-ilmu agama adalah ilmu utama dalam proses pendidikan yang terlembagakan. Dalam kerangka seperti itu maka ilmu agama khususnya fiqh dinobatkan sebagai mahkota ilmu. ${ }^{7}$ Lebih dari itu, tidak kurang dari tiga status yang diberikan pada mereka yang telah menempati posisi puncak tersebut, yaitu faqi>h,mufti dan mudarris. 8 Dalam kenyataannya, tiga status tersebut secara eklusifn menjadi hak penuh para doctor $f i q h$ (hukum). Oleh karena itu Makdisi berpendapat bahwa berdirinya Madrasah memiliki kaitan erat dengan pembentukan madzhab. ${ }^{9}$ Dalam posisi semacam ini, seorang ahli hukum (fuqaha $>$ ) menempati posisi yang tertinggi dan syeikh sebagai pengampu pengajaran ilmu-ilmu yang lain berada dibawahnya. ${ }^{10}$

Keududukan fiqh yang memuncak menjadikan ilmu-ilmu yang lain menjadi termarjinalkan. Menurut Azzumardi Azra, ada tiga hal yang melingkupinya; (1)berkaitan dengan pandangan ketinggian syari ah diatas ilmu-ilmu yang lain; (2)secara intitusi kelembagaan pendidikan Islam dikuasai oleh mereka yang ahli dalam bidang agama; dan (3) Hampir seluruh madrasah didirikan dan dipertahankan dengan dana wakaf dari dermawan kaya atau penguasa politik Muslim. ${ }^{11}$ Dengan demikian, dapat dikatakan dalam tubuh pendidikan Islam mulai muncul dikotomi dan dualism yang terang terjadi dilembaga pendidikan Islam.

Dampaknya, jurang pemisah antara makna integral keilmuan dan keislaman menjadi semakin lebar.Hal ini berdampak muatan ilmu pengetahuan umum terlalu jauh dari nilai agama dan ilmu agama sama sekali tidak menjamah keilmuan umum. Hal ini didasarkan pada perlengkapan keilmuan yang terlalu minim untuk mampu bergumul dengan realitas yang mencekam. ${ }^{12}$ Melihat realitas keterpurukan dan ketertinggalan tersebut, dalam dunia Islam kontemporer muncul para pemikir yang gelisah dan menelorkan gagasan-gagasan dalam rangka mengejar ketertinggalan pendidikan Islam. Tokoh-tokoh seperti Fazlur Rahman, Seyyed Hossein Nasr, Ismail Raji al-Faruqi dan Syekh Muhammad NaquibalAttasadalahsedikitcontohdari para tokoh kontemporer dan masih banyak yang lainnya bersama-sama merumuskan pembaharuan dalam bidang pendidikan Islam.

\section{Paradigma Integrasi Islam, Sains, dan Ilmu Pengetahuan}

Setelah jauh melangkah menelusuri akar dikotomi dan dualisme pendidikan Islam, kesimpulan awal yang dapat kita ambil adalah faktor kemunduran umat Islam saat ini adalah adanya dikotomi dan dualisme pendidikan Islam. untuk itupara pemikir Islam mencoba membuat formulasi dan konsep baru dalam rangka meretas dikotomi dan dualisme tersebut. Pada bagian ini akan dibahas mengenai gagasan 
paradigm yang dibangun oleh pemikir-pemikir Islam kontemporer dalam usahanya menggagas sebuah bangunan keilmuan yang memadukan unsur-unsur agama dan ilmu. Dengan keterbatasan yang penulis miliki dan tidak bermaksud mengenyampingkan pemikir yang lain, paling tidak ada tiga tokoh yang akan dibahas dalam tulisan ini, yaitu: Muhammad Naquib, Kuntowijoyo, dan M. AminAbdullah.

a. Islamisasi Ilmu Pengetahuan(Sayed Naquibal Attas)

Sayed Naquib Al-Attas seorang pemikir dalam dunia Islam yang kemudian menyadari bahwa ilmu pengetahuan modern ternyata syarat dengan nilai barat. Untuk mencapai kebenaran, ilmu tersebut sangat mengedepankan akal rasional, dampaknya nilai-nilai dan pesan keagamaan menjadi terabaikan. Bagial-attas keilmuan barat dibangun atas kerguan, kebingungan, skeptitis medan tidak dibangun atas wahyu dan kepercayaan agama, sehingga menjadi sekuler dan tidak mengindahkan nilai-nilai etika. ${ }^{13}$ Berdasarkan fenomena tersebut maka yang harus dilakukan oleh para ilmuwan muslim adalah dengan Islamisasi ilmu pengetahuan. Bagi al-Attas, Islamisasi merupakan "pembebasan manusia mulai dari magis, mitos, animisme, dan tradisi kebudayaan kebangsaan dan kemudian dari penguasaan sekuler atas akal dan bahasa. ${ }^{14}$ Bagi al-Attas, aplikasi Islamisasi ilmu pengetahuan diwujudkan dengan mengubah konsep-konsep Islam yang terdiri dari (1) manusia; (2) din; (3) ilm dan ma'rifah; (4) hikmah; (5) 'adl; (6) amal-'adah; (7) konsep universitas. ${ }^{15}$ Al-attas meninginkan aplikasi islamisasi ilmu pengetahuan merupakan usaha mengislamkan konsep-konsep keilmuan Barat kepada konsep tauhid, syari'ah, sirah, dan tarikh sehingga hasilnya adalah sains Islam, psikologi Islam, sosiologi Islam, ekonomi Islam yang lebih subtantif, karena konsep-konsep dasarnya berdasarkan Islam. ${ }^{16}$

Dari paparan diatas, dapat diambil kesimpulan bahwa langkah yang diambil al-Atas dalam rangka Islamisasi ilmu pengetahuan adalah dengan berangkat dari konteks dimana sebuah ilmu itu lahir dan adan kemudian diangkat kedalam teks wahyu. Dengan pandangan yang semacam ini, nampaknya akan menimbulkan dilema yang terjadi yaitu terlihat kemungkinan dimensi Islam akan sangat meluas. Konsekuensi konsep ini adalah Islam tidak hanya terbatas pada teks suci dan teologis, namun bisa meluas pada wilayah yang dianggap duniawi.

b. PengilmuanIslam(Kuntowijoyo)

Kuntowijoyo melakukan kritik terhadap paradigm Islamisasi ilmu pengetahuan berangkat dari ketidaksepakatannya dengan penggunaan istilah Islamisasi ilmu pengetahuan untuk melakukan "syahadat" terhadap ilmu-ilmu sekuler. Menurutnya bahwa dalam rangka Islamisasi pengetahuan, umat Islam harus meninggalkan makna lama yaitu Islamisasi pengetahuan menuju paradigm baru yaitu pengilmuan Islam. ${ }^{17}$ Paradigma tersebut dirasa lebih tepat karena jika masih menggunakan paradigm Islamisasi ilmu pengetahuan, maka yang terjadi adalah adanya realitas historis yang ditarik dan "dipaskan" pada teks wahyu. Hal tersebut memang dapat menimbulkan konfik karena Dengan kebenaran wahyu yang abadi akan terancam oleh benturan-benturan perdebatan dan falsifikasian tari lmu pengetahuan dan teori. Berangkat dari kemungkinan buruk tersebut, Kontowijoyon menggunakan konsep pengilmuan Islam yang berangkat dari teks kekonteks, maka konsep ini dipandang lebih tepat dan tidak rekasionaer terhadap upaya penyatuan Islam dan ilmu pengetahuan.

Adapun metodologi yang ditawarkan Kuntowijoyo dalam konsep pengilmuan Islam ada dua. Pertama integralisasi yaitu pengintegrasian kekayaan keilmuan manusia dengan wahyu (petunjuk Allah dalam Al-Qur'an besertapelaksanaannya dalam sunah Nabi). Kedua objektifikasi yaitu menjadikan pengilmuan Islam sebagai rahmat untuk semua orang. ${ }^{18}$ Menurut Kuntoada perbedaan paradigmatik antara ilmu-ilmu sekuler dengan ilmu-ilmuintegralistik. Hal ini 
didasarkan pada apa yang dimaksud Thomas Khundalam The Structure of Sceintific Revolution, bahwa ilmu-ilmu sekuler sebagai normalsciences dan ilmu-ilmu integralistik adalah suatu revolusi.

c. Integrasi Interkoneksi Keilmuan (M.AminAbdullah)

Integrasi secara bahasa diartikan sebagai "berlawanan dengan pemisahan", yaitu usaha memadukan ilmu umum dan ilmu agama. ${ }^{20}$ Secara lebih mendalam Armahedi Mazhar melihat inti dari integrasi adalah meletakan hirarki keilmuan dalam suatu hirarki yang lebih besar dengan memasukan alam akherat dan ciptaan Tuhan itu sendiri sebagai penunjang jenjang materi. ${ }^{21}$ Perbedaan yang mendasar antara Islamisasi ilmu pengetahuan, dan integrasi adalah dalam hal pelumatan keilmuan umum dan agama. ${ }^{22}$ Dalam Islamisasi ilmu, keilmuan Islam akan memilih ilmu-ilmu yang dianggap Islami dan ilmu yanh bukan Islami dengan menghilangkan ilmu-ilmu yang bukan Islami atau tidak cocok dengan Islam. ${ }^{23}$ sedangkan integrasi dalam hal ini berkaitan dengan usaha memadukan keilmuan umum dan Islam tanpa harus menghilangkan keunikankeunikan antara dua keilmuan tersebut. ${ }^{24}$

Namun demikian, dalam pandangan Amin Abdullah, integrasi mengalami kesuliatan, yaitu kesulitan memadukan studi Islam dan umum yang kadang tidak saling akur karena keduanya ingin saling mengalahkan untuk itu perlu adanya gagsan interkoneksi yang lebih arif dan bijaksana. ${ }^{25}$ Adapun yang dimaksud interkoneksi menurut Amin Abdullah adalah usaha memahami kompleksitas fenomena kehidupan yang dihadapi dan dijalani manusia, sehingga setiap bangunan keilmuan apapun, baik keilmuan agama (Islam, Kristen, Budha, dan lain-lain) keilmuan sosial, humaniora, maupun kealaman tidak dapat berdiri sendiri maka dibutuhkan kerjasama, saling tegur sapa, saling membutuhkan,saling koreksi, dan saling berhubungan antara disiplin keilmuan. ${ }^{26}$

Pendekatan integratif-interkonektif adalah pendekatan yang berusaha saling menghargai; keilmuan umum dan agama sadar akan keterbatasan masing-masing dalam memecahkan persoalan manusia, hal ini akan melahirkan sebuah kerja sama setidaknya saling memahami pendekatan (approach) dan metode berfikir (process and procedure) antara kedua kelimuan tersebut. ${ }^{27}$

Setelah dipaparkan ketiga paradigma usaha mendamaikan Islam dan ilmu pengetahuan,sekali lagi saya memberikan apresiasi yang besar atas karya akademik tersebut. Namun demikian, sayangnya usaha mendamaikan ilmu tersebut tidak disertai dengan usaha mendamaikan lembaga pendidikan. Usaha yang dilakukan masih sebatas pada usaha mendamaikan pada wilayah materi Islam dan ilmu pengetahuan sehingga permasalahan dikotomi dan dualisme lembaga pendidikan Islam masih belum dapat diatasi secara keseluruhan.

\section{Kebijakan yang Menceraikan Lembaga Pendidikan Islam}

Selanjutnya, jalan panjang dualism dan dikotomi pendidikan juga merambah dan sampai di Indonesia. Permasalahan dikotomi dan dualisme pendidikan di Indonesia tidak bisa dilepaskan dilepaskan dari potret sejarah masa lalu (masa penjajahan). Karel Steenbrink menjelaskan secara kritis bahwa pemerintah belanda ingin membangun system pendidikan yang berdasarkan sistem pribumi murni dan disesuaikan dengan masyarakat desa, yang dikaitkan dengan pendidikan Islam yang sudah ada sebelumnya. ${ }^{28}$ Apa yang disebutkan oleh Stennbrink merupakan gagasan Gubernur Jenderal Van Der Capellen. Menurut Brugmans usaha yang dilakukan oleh Van Der Capellen adalah usaha untuk mewujudkan kebijakan politik Belanda, yaitu: harus menghormati unsur pribumi dalam masyarakat dan 
keengganan menolak kebudayaan asli dalam hubungannya kebudayaan asing yang bercorak barat. ${ }^{29}$ Namun demikian, karena berbagai alasan teknis, kebijakan tersebut akhirnya tidak dilaksanakan.

\section{Konversi IAIN UIN (Sebuah Kritik)}

Memang benar, ada catatan penting yang termaktub dalam surat Mendiknas yang ditujukan kepada menteri Agama, tanggal 23 Januari 2004 yaitu: "Meskipun IAIN Sunan Kalijaga dan STAIN Malang berubah menjadi UIN Sunan Kalijaga Yogyakarta dan UIN Malang, namun tugas pokoknya tetap sebagai instusi pendidikan tinggi bidang agama Islam, sedangkan penyelenggaraan program non-agama Islam (umum) merupakan tugas tambahan".35 Namun demikian, catatan ini pada realitasnya sulit untuk diimplementasikan. Sekali lagi tuntutan pasar yang memaksa UIN akan berlomba membuka fakultas umum dan pada akhirnya fakultas tersebut akan menggeser fakultas agama seperti yang terjadi di UII dan Universitas Muhammadiyah di seluruh Indonesia. Berkenaan dengan hal tersebut, perlu saya sampaikan ada empat pertimbangan yang disampaikan oleh Ahmadi untuk kita perhatikan bersama, pertimbangan tersebut adalah sebagai berikut:

Pertama, berdasarkan pengalaman sejarah, dalam pengembangan pendidikan syahwat politik umat Islam sangat dominan. Kecenderungan politis yang dipayungi dengan landasan teologis, Nampak ketika umat Islam beramai-ramai mendirikan perguruan tinggi tanpa studi kelayakan akademis. Sekarang di seluruh Indonesia terdapat 14 IAIN, 33 STAIN, dan ratusan PTAIS (khusus Jawa Tengah ada 25 PTAIS). Ketika animo mahasiswa semakin kurang mereka kebingungan, akhirnya berusaha membuka program pendidikan umum yang diperkirakan laku jual. Ketikalulusannya ditolak untuk mendaftarkan calon pegawai negeri, semakin bingung lagi karena dibayangi kematian pelan-pelan. Oleh karena itu, dalam konteks UIN syahwat politik mesti ditinggalkan dan pertimbangan akademis harus benar-benar dipegang teguh. Kalau hal ini tidak dilakukan hampir bisa dipastikan di kemudian hari nasibnya akan sama dengan PTAI.

Kedua, perlu dipertimbangkan konsekuensi penggunaan predikat Universitas Islam Negeri, yakni karakteristik apa yang dapat ditawarkan. Misalnya landasan epistemologinya yang secara eksplisit berbeda dengan tinggi lain, wawasan keislaman yang relatif lebih luas, dan komitmen terhadap Islam lebih tinggi dibandingkan dengan perguruan tinggi lain.

Ketiga, Keberadaan UIN sekarang masih menunjukkan dualism kelembagaan. Misalnya berdasarkan Kepres No. 50 tahun 2004 tentang perubahan IAIN Sunan Kalijaga menjadi UIN Sunan Kalijaga Yogyakarta, pasal 2 ayat (2) bahwa UIN Sunan Kalijaga secara teknis akademis bidang ilmu umum dibina oleh Kementerian Pendidikan dan Kebudayaan (Kemdikbud) dan secara teknis fungsional dibina oleh Kementerian Agama. Dualisme kelembagaan ini sudah semestinya dihilangkan, serahkan saja sepenuhnya ke Kemdikbud agar prinsip efisiensi dan fungsional dapat dijalankan karena secara fungsional yang tepat mengurus pendidikan adalah Kemdikbud. Beban politis ideologis sudah selayaknya dihilangkan, artinya tidak perlu khawatir nilai dan pesan-pesan agama Islam terdistorsi karena sudah ada undang-undang pendidikan nasional yang menjamin tumbuh kembangnya niali-nilai agama dalam pendidikan formal.

Keempat, dengan diserahkannya UIN ke Kemdikbud mestinya member peluang yang sama kepada universitas-universita selain yang akan membuka fakultas agama (Islam) untuk ikut memperdalam dan mengembangkan ilmu pengetahuan agama Islam secara akademis. Hal ini jangan dianggap rival, tetapi justru memperluas medan musābaqahfial-khairat dalam keilmuan. ${ }^{36}$ 


\section{Hibridasi Lembaga Pendidikan Tinggi}

Seperti yang telah disampaikan pada pembahasan sebelumnya bahwa akar keterpurukan penguasaan ilmu pengetahuan Islam adalah karena adanya dikotomi dan dualisme lembaga pendidikan Islam. Dalam konteks pendidikan di Indonesia polarisasi lembaga pendidikan ini juga dimulai dari catatan yang panjang yaitu pada masa pemerintahan kolonial. Untuk menajawab permasalahan tersebut telah ada upaya yang dilakukan misalnya dengan transformasi IAIN ke UIN. Namun pertanyaan selanjutnya adalah haruskah permasalahan tersebut diselesaikan dengan konversi IAIN ke UIN? Pertanyaan besar tersebut yang selalu menjadi perdebatan panjang untuk menyelesaikan dikotomi dan dualisme lembaga pendidikan Islam. Namun demikian, tentu pendapat tersebut belum menjadi consensus bersama, ada yang menganggap ketika umat Islam sudah mengatakan perlu ada Islamisasi ilmu atau integrasi ilmu, maka kita sudah menyepakati adanya dikotomi Islam dan ilmu. Padahal jika kita berangkat dari keyakinan bahwa seluruh ilmu berasal dari Tuhan maka sejatinya tidak ada pemisahan antara ilmu agama dan ilmu umum.

Untuk menjawab pertanyaan diatas, tentu ada banyak pandangan dan pendapat yang saling mendukung atau bahkan saling bertentangan. Tulisan ini hendak memberikan pandangan yang mungkin dianggap bersebarangan, bukan bermaksud untuk melakukan perlawanan secara terbuka, namun dalam rangka sumbangsih pemikiran untuk menjadikan segalanya menjadi lebih baik. Salah satu pandangan yang menarik adalah apa yang disampaikan Ahmadi yang dikutip Rosihan bahwa dalam rangka menanamkan nilai-nilai agama pada ilmu modern tidak selamanya dan harus menggunakan jalur pemisahan lembaga pendidikan agama dan umum.

Ahmadi membuat perbandingan dinegeri Belanda dalam penelitiannya tahun 1993-1994 tentang studi agama di Belanda, bahwa negara yang menganut paham sekuler, masalah pendidikan agama di Perguruan Tinggi yang bermuatan pesan-pesan spiritualitas dijembatani dengan peraturan perundang-undangan yang disebut dengan Duplet Ordo dengan produk pendeta-pendeta Kristen yang mempunyai komitmen kuat dengan agamanya. ${ }^{39}$ Artinya nilai-nilai dan pesan agama ditanamkan pada setiap perguruan tinggi dengan komposisi yang besar dan menjadikannya sebagai dasar yang kuat bagi seluruh ilmu umum. Jika Belanda sebuah negara yang sekuler juga mampu melaksanakan Pendidikan Agama diperguruan tinggi dengan pendekatan religius, maka Indonesia dengan Negara beragama sudah pasti jauh lebih mampu melaksanakannya.

Seperti yang telah disebutkan, memang ada banyak gagasan bermunculan tentang langkah-langkah yang harus ditempuh dalam upaya menjadikan nilai Islam sebagai pondasi ilmu pengetahuan. Hal ini menjadi penting akrena ketika ilmu pengetahuan tidak dilandasi dengan nilai agama yang mantap, maka ilmu itu akan digunakan kepada hal yang jauh dari nilai etika dan moral. Iman yang tidak disertai ilmu, mudah ditipu, demikian sebaliknya ilmu tanpa iman, menjadi penipu. 40

Dalam bagian ini, penulis akan mencoba memberikan gagasan mendasar tantang upaya yang harus dilakukan agar pesan-pesan agama masuk kedalam seluruh ilmu umum yang ada. Berdasarkan pada permasalahan tentang tidak efektifnya pola-pola integrasi dan islamisasi yang dilakukan, maka penulis menawarkan gagasan yang mungkin cukup kontroversial yaitu dengan meleburkan lembaga pendidikan Islam dengan lembaga pendidikan umum. Ikhtiar ini terangkum dalam konsep yang saya namakan hibridasi lembaga pendidikan tinggi. Ada beberapa alasan yang menjadi dasar gagasan tersebut.

Pertama, lembaga pendidikan tinggi Islam yang selama ini digadang-gadang menjadi lembaga pendidikan Islam yang mampu mengentarkan para mahasiswanya menjadi ulama yang intelek dan intelek yang ulama nampaknya telah gagal mengemban amanah tersebut. Indikator sederhananya adalah belum banyak sarjana dari lembaga pendidikan tinggi Islam yang membuka fakultas umum belum mampu bersaing secara terbuka dalam bidang penguasaan ilmu pengetahuan. Walaupun memang alasanya adalah 
waktu yang masih singkat tapi nampaknya tanda-tanda adanya perbedaan yang signifikan belum nampak. Ini menandakan bahwa mitos lembaga pendidikan tinggi Islam hanya bertumpu pada penguatan materi agama masih berlaku.

Kedua, secara keseluruhan lembaga pendidikan tinggi Islam baik negeri maupun suasta belum menjadi pilihan pertama para orang tua untuk mempercayakan pendidikan anak-anaknya, gedung dan fasilitas pengembangan ilmu pengetahuan yang kurang lengkap, dosen dengan kompetensi akdemiknya minim, serta hal-hal lain yang berakibat pada lembaga pendidikan tinggi Islam hanya akan menjadi pilihan selanjutnya ketika tidak diterima di lembaga pendidikan tinggi umum. Dengan demikian, input yang ada pada lembaga pendidikan tinggi Islam jelas berada pada level bawah dari lembaga pendidikan tinggi umum.

Ketiga, materi agama yang diajarkan pada fakultas-fakultas agama dan materi agama yang diajarkan pada fakultas umum sangat rentan dengan kepentingan politis suatu golongan saja. Misalnya dalam materi pelajaran fiqh, doa-doa bacaan shalat dan tata cara shalat dan ibadah yang lain cenderung hanya memberikan contoh bacaan ataupun gerakan-gerakan dari satu sumber saja. Padahal seperti yang kita ketahui bersama, bahwa bacaan dan gerakan tersebut sebenarnya tidak hanya dari satu sumber saja yang sama-sama shahih. Dengan demikian, materi agama yang ditawarkan tidak mampu menampung seluruh golongan agama dengan keyakinan ibadahnya masing-masing.

Berdasar beberapa alasan diatas, maka penulis menyarankan beberapa gagasan yang walaupun akan memakan waktu yang sangat lama, namun harapannya hasilnya dapat dirasakan dan apa yang menjadi keinginan bersama bahwa nilai-nilai agama dapat tumbuh dan bersama ilmu umum dapat terwujud. Beberapa tawaran konsep tersebut adalah sebagai berikut:

Pertama, melakukan hibridasi atau penggabungan lembaga pendidikan tinggi Islam dan lembaga pendidikan umum dalam sebuah format baru. Dengan demikian, paling tidak secara menajemen dan kebijakan menjadi lebih efektif dan efisien karena hanya berada pada satu atapdan satu kendalai.

Kedua, melakukan penggabungan materi agama dan materi ilmu pengetahuan umum menjadi satu materi ilmu pengetahuan umum. Pengagabungan ini dengan maksud merubah materi-materi yang berangkat dari logika yang lahir dari keilmuan sekuler murni dengan materi yang dilandaskan pada nilainilai agama universal. Hal ini dilakukan karena ilmu tidak bebas nilai dan nilai.

Ketiga, memberikan pemahaman dan peningkatan kualitas dosen matakuliah umum tentang nilainilai agama pada matakuliah yang mereka ampu. Mata kuliah umum yang dimaksud meliputi seluruh mata kuliah ilmu yaitu sains, sosial, dan humaniora. Dengan demikian, para dosen mata kuliah umum mampu menerapkan dan menyampaikan materi yang bermauatan nilai Islam

Kempat, pemerintah menyusun kurikulum dan materi kuliah umum yang berisi muatan yang nilainilai agama universal pada seluruh matakuliah ilmu pengetahuan umum. Dengan catatan nilai-nilai tersebut adalah nilai-nilai Islam universal yang bisa disepakati bersama oleh seluruh umat Islam. Artinya bukan pada wilayah materi ibadah, muamalah dan setrusnya yang memungkinkan terjadinya perbedaan. Karena wilayah ibadah adalah wilayah privat hamba dan Tuhannya.

Jika tiga usulan tersebut dapat dipraktekan walaupun disadari memerlukan waktu yang panjang, namun penulis yakin bahwa nilai-nilai agama akan masuk

dan menjadi pondasi bagi seluruh ilmu umum yang ada. Selain itu, konsep ini juga diharapkan akan menghasilkan alumni yang mempunyai etika dan moral yang kuat dalam mempraktekan ilmunya untuk kesejahteraan bersama. Jika hal demikian terjadi, maka cita-cita mulia lulusan perguruan tinggi menjadi ulama yang intelek dan intelek yang ulama nampaknya akan semakin dekat dengan kenyataan. 


\section{Kesimpulan}

Hibridasi lembaga pendidikan adalah sebuah penggabungan secara total lembaga pendidikan tinggi Islam dan pendidikan tinggi umum dalam satu naungan lembaga dan kebijakannya berada dibawah Kementerian Pendidikan dan Kebudayaan. Dengan demikian dari sisi manajemen kelembagaan dapat lebih efektif dan efisien. Selain masalah kelembagaan dalam wacana hibridasi ini juga dalam wilayah kurikulum pendidikan dimana Islam dan ilmu umum diintegrasikan. Diperlukan kurikulum baru yang menggabungkan materi matakuliah umum dan Islam dalam bentuk satu materi yakni seluruh materi umum didasari dengan nilai Islam yang universal. Dalam hal ini, mata kuliah ke-Islaman tidak berdiri sendiri, namun dicangkokkan ke dalam mata kuliah umum yang lain. Walaupun matakuliah ke-Islaman dihapus, namun materi pengajaran berupa nilai-nilai Islam masuk ke dalam setiap mata kuliah yang ada. Sehingga, setiap matakuliah mengandung pengajaran ke-Islaman sebagai landasan moral dan etika dalam berilmu.

Selanjutnya, perlu dipersiapkan para dosen yang memiliki wawasan etika Islam. Seperti yang kita ketahui bahwa dalam ranah aksiologi ilmu, seorang intelektual memerluakan pegangan moral sehingga ilmu yang dimiliki bisa menjadi berkah kemanusian, bukan bencana. Disinilah nilai-nilai kemanusian Islam perlu disematkan pada setiap pengajar diperguruan tinggi.

Hibridasi dalam materi secara teknis, materi Islam yang diintegrasikan pada materi pengetahuan umum bukan pada wilayah ibadah, muamalah namun pada nilai Islam yang juga dapat diterima oleh semua golongan bahkan lintas agama. Jika hal tersebut terjadi maka materi ilmu umum akan didasari dengan nalar Islam dan mahasiswa akan dapat mengamalkan ilmunya untuk hal kebaikan dan kesejahteraan bagi seluruh umat dan sekalian alam. Dengan pencangkokan dalam empat ranah tersebut, Islam tidak akan pudar, namun menggema disetiap disi plin keilmuan yang dipelajari, selain itu ilmu tidak hampa akan moral dan nilai-nilai Islam yang universal.

\section{Referensi}

Abdullah, Amin. "Desain Pengembangan Akademik IAIN menuju UIN Sunan Kalijaga: dari pendekatan Dikotomis-Atomistis ke arah integratifinterdisiplinary" dalam Achmadi, Ideologi Pendidikan Islam: Paradigma Humanis Teosentris, Yogyakarta: Pustaka Pelajar, 2008.

Abdullah, Amin. Islamic Studies di Perguruan Tinggi: Pendekatan Integratif-Interkonektif. Yogyakarta: PustakaP elajar. 2006.

Ahmadi, dalam Rozihan. Merombak Pendidikan Islam. Koran Suara Merdeka. 7 Januari 2005.

Azra, Ayzumardi. "Reintegrasi ilmu-ilmu dalam Islam". Zainal Abidin Bagir, (ed)

Integrasi Ilmu dan Agama: Intepretasi dan Aksi. Bandung: Mizan. 2005.

Azra, Azyumardi. Pendidikan Islam:T radisi dan Modernisasi menuju Milenium Baru. Jakarta:LOGOS. 1999.

Dokumen Surat Menteri Pendidikan Nasional, dalam M. Amin Abdullah, dkk. Islamic Studies dalam Paradigma Integrasi-Interkoneksi, Yogyakarta: Suka Press. 2007. 
Hasim, Rosnani. "Gagasan Islamisasi Ilmu Pengetahuan Kontemporer: Sejarah, Perkembangan Dan Arah Tujuan”, Islamika, Tahun 1 No 6, Juli-September 2005.

Hitti, K. Philip. History of The Arab, London: Macmillan Press Ltd. 1974 Hourani, Albert. A history of Arab Peoples, New York: Warner Books,1992 Kartanegara, Mulyadi. Integrasi Ilmu:

Sebuah Rekontruksi Holistik. Bandung:

Arasyi Mizan. 2005.

Kuntowijoyo. Islam sebagai Ilmu: Epistemologi, Metodologi dan Etika. Yogyakarta: Teraju. 2004.

Ma'arif, A. Syafi’i. Peta Bumi Intelektual Islam di Indonesia. Bandung: Mizan. 1993.

Mahzar, Armahedi. Revolusi Integralisme Islam. Bandung: Mizan, 2004. Maksidi,

George. Religion, Law and Learning. Great Britain:Voriorum. 1991 